International Journal of Agriculture, Environment and Bioresearch

Vol. 06, No. 02; 2021

ISSN: $2456-8643$

\title{
MORPHOLOGICAL EVALUATION OF CYDONIA OBLONGA SORT IN GENETIC BANK OF ALBANIA
}

\author{
*Tatjana Kokaj \\ Institute Of Plant Genetic Resources (Agricultural University Of Tirana), Albania \\ https://doi.org/10.35410/IJAEB.2021.5619
}

\begin{abstract}
The quince is the sole member of the genus Cydonia in the family Rosacea. It is a deciduous tree that bears a pome fruit, similar in appearance to a pear, and is bright golden-yellow when mature. The raw fruit is a source of food. Cydonia oblonga is a type of tree that lies on the borders of the Continental and Mediterranean region. Albania country has rich quince genetic resources. In particular, the central part of the country and south of country. Cydonia oblong is hard fruit is sweet. In Albania country this tree is cultivated in older time and find in some zones of our country and center zone of our country. Cydonia is piece of tradition of our country in orchard, in family garden. The destination of fruit is for fresh consume, syrup, marmalade, jam, (aim of market). In Gene Bank collection some sorts of Cydonia oblonga are collected from different zones of our country. The aim of this study is evaluation morphological traits for accession Cydonia which are found in collections. Those sorts at this moment are in full productivity and exposed genetic diversity in forms of fruit, in color of fruit, in taste of fruit, in size of fruit etc. In this study, statistical analyses for some traits such is diameter of the fruit and the weight of the fruit, sugar \%, correlation between sorts, using international descriptors were used. The study distinguished two groups of cultivar in relation to the shape of the fruit, color fruit, gold color fruit is best than other sorts and sorts which are preferred from industry.
\end{abstract}

Keywords: Size, sugar, weight, sort, characterization, diversity.

\section{INTRODUCTION}

Cydonia is a very old fruit. The place of origin of this tree is thought to be between the Caspian Sea and the Black Sea, in the Trans-Caucasus region.

For over 4000 years, the cold tree grows in Asia, the Mediterranean and is found in Latin America, the Far East and the USA, with much interest in the antiquity of this fruit.

-The first name of the cydonia variety of Greek origin is Cydonia melon, which means apple from

Cydonia was a major city in the west of the island of Crete and the cold tree was autochthonous. The Greeks dedicated the invitation to Aphrodite, the goddess of beauty. The Biblical name of Cydonia, translated as golden apple. 
Vol. 06, No. 02; 2021

ISSN: 2456-8643

The ancient Greeks tell not only about the medicinal values of the fruit but also about its extracts.

In the past the invitation topped the list of fruits, for the high content of pectin.

The cold tree is a mythical fruit that was cultivated very early and older than apples and pears, which are in the same family. The quince fruits are also known as an important dietary source due to its antioxidant, antimicrobial and ant ulcerative properties (Silva et al 2004, Ha mauzu et al 2006, Fattouch et al 2007). The characterization of the quince genotypes were performed primarily based on phenotypic traits of the plants such as color, size, shape and other agronomical characters of fruit (Ercan et al 1992, Ercisli et al 1999, Dumanogu et al 2009, Kuden et al 2009). The, environmental genotype traits are necessary for identification of genetic diversity among quince accessions. Cydonia is classified in the group of seeds which include:

Apple; 2. Pear; 3. Cydonia.

The origin of the cydonia tree is older than the apple tree and the pear tree but for years it has been behind the apple and pear for economic, productive reasons and market demands.

This tree has a feature that in geographical extent it is between areas with Mediterranean and Continental climatic conditions. Resistant to temp up to - $23 \mathrm{C}$, roots resist up to temp $-12 \mathrm{C}$, flowers resist down to -1 to $-1.5 \mathrm{C}$. this tree is drought resistant and produces very well in the amount of precipitation from $600-900 \mathrm{~mm}$ of rain during year.

Purpose of this study: To evolve and characterize some features of cold accesses found in the field collection of genetic resources (Genetic Bank).

Deadline: $2017,2018,2019$

Place: Valias germplasm field, (ex situ)

Objective 1: To verify the identity of the accesses included in the ex situ collection.

Objective 2: To characterize some qualitative features of invitation accesses.

Objective 3: To evaluate the genetic diversity of diversity of ftoit accessions in the ex situ collection (Genetic Bank).

\section{MATERIAL AND METHODS}

The study was performed on the field collection of germoplasm of fruit tree. 10 genotypes in three replications. All the necessary indicators of fruit, leaf were taken according to the descriptors of IPGRI. The mainly indexs of fruit as below. Forms of fruit, color of fruit, weight of fruit, dimension of fruit, Forms of leaves, dimension of leaves, \% of sugar, etc. In this study the method was applied ANOVA program of statistic analyses.

\section{RESULT AND DISCUSSION}


Vol. 06, No. 02; 2021

ISSN: $2456-8643$

The study was able to identify the types of cold accesses, compared to their country of origin, based on the data documented in the documentation inventory. The study was able to identify the types of accessions introduced in the genetic collection.

In the characterization of the features mainly in the fruits, it was possible to characterize the features such as the shape of the fruit, the color of the fruit, the taste of the fruit, the $\%$ of fruit sugar, the resistance after harvest.

Features such as leaf shape for each access, crown shape, disease resistant

Fruit mass is a quantitative indicator and is different in different species, an indicator that depends on agronomic conditions but also genetic ones, dominated by large and medium-sized forms.

The taste of the fruit is relatively sweet but that is associated in some genotypes with wrinkles in the mouth.

The percentage of sugar depends on the baking time and temperatures. Table no. 2 gives the percentage of sugar for each type.

Indicators $14 / 1 ; 13 / 1 ; 18 / 2 ; 19 / 1 ; 22 / 2$ for all cydonia genotypes are the same.14/1 = use of fruit; $15 / 1=$ for fruit production; $18 / 2=$ Average tree strength, $19 / 1=$ Erect and semi-erect crown shape, $22 / 2=$ Leaf base mass $=$ average.

The color feature of the flower is two types white and pink.

$-33 / 2$ which has to do with the feature of max of the diameter of the fruit, is the same for all genotypes of the fruit, max is around the middle of the fruit.

The other feature is the color of the fruit which moves from green to light green, dark green, yellow to yellow and yellow to gold. The dominant trait in the genotypes found in the collection are dark green, yellow-green and yellow-gold. I would single it out in gold. The shape of the fruit is pear-shaped, elongated and irregular, $42 / 2$ is a good dominate,physiologicharvest43/3dominates, good - commercial harvest.Other trait is color of fruit which moving from green color to white green color, green on

Yellow color and yellow to gold color. Dominant trait of genotypes which found on collection are dark green color, green to yellow color and yellow color to gold color. I will the color with gold for qualitative traits, organoleptic traits.

Forms of fruit are in pear form, apple form elongated and disorder form of fruit, 42/2 - good/ dominant accession, physiology harvest $43 / 3$ is good, harvest is comerciale.

Table no 1: Index's of quince tree varieties in collection of Valais

\begin{tabular}{|l|l|l|l|l|l|l|l|}
\hline No & $\begin{array}{l}\text { No } \\
\text { code }\end{array}$ & $\begin{array}{l}\text { Plant } \\
\text { use }\end{array}$ & $\begin{array}{l}\text { Fruit } \\
\text { use }\end{array}$ & $\begin{array}{l}\text { Tree } \\
\text { vigor }\end{array}$ & Plant habit & $\begin{array}{l}\text { Size of } \\
\text { leaf blade }\end{array}$ & $\begin{array}{l}\text { Color } \\
\text { flower }\end{array}$ \\
\hline
\end{tabular}


Vol. 06, No. 02; 2021

ISSN: 2456-8643

\begin{tabular}{|l|l|l|l|l|l|l|l|}
\hline 1 & 3172 & $14 / 1$ & $15 / 1$ & $18 / 2$ & 19.1 & $22 / 2$ & white \\
\hline 2 & 3370 & $14 / 1$ & $15 / 1$ & $18 / 2$ & 19.1 & $22 / 2$ & white \\
\hline 3 & 3373 & $14 / 1$ & $15 / 1$ & $18 / 2$ & 19.1 & $22 / 1$ & white \\
\hline 4 & 3173 & $14 / 1$ & $15 / 1$ & $18 / 2$ & 19.2 & $22 / 2$ & white \\
\hline 5 & 3318 & $14 / 1$ & $15 / 1$ & $18 / 2$ & 19.1 & $22 / 1$ & white \\
\hline 6 & 3141 & $14 / 1$ & $15 / 1$ & $18 / 2$ & 19.1 & $22 / 1$ & white \\
\hline 7 & 3246 & $14 / 1$ & $15 / 1$ & $18 / 2$ & 19.1 & $22 / 2$ & pink \\
\hline 8 & 3139 & $14 / 1$ & $15 / 1$ & $18 / 2$ & 19.2 & $22 / 1$ & pink \\
\hline 9 & 3295 & $14 / 1$ & $15 / 1$ & $18 / 2$ & 19.2 & $22 / 2$ & pink \\
\hline 10 & 3287 & $14 / 1$ & $15 / 1$ & $18 / 2$ & 19.2 & $22 / 2$ & pink \\
\hline
\end{tabular}

Table no 2: Index's of fruit quince varieties in collection of Valias

\begin{tabular}{|c|c|c|c|c|c|c|c|c|c|c|}
\hline $\begin{array}{l}\mathbf{N} \\
\mathbf{O}\end{array}$ & $\begin{array}{l}\text { No } \\
\text { code }\end{array}$ & $\begin{array}{l}\text { Positi } \\
\text { on of } \\
\text { max } \\
\text { diame } \\
\text { ter on } \\
\text { fruit }\end{array}$ & $\begin{array}{l}\text { Color } \\
\text { fruit }\end{array}$ & $\begin{array}{l}\text { Time of } \\
\text { fruit } \\
\text { ripenin } \\
\mathrm{g}\end{array}$ & 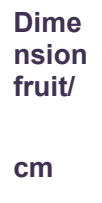 & $\begin{array}{l}\text { Weight } \\
\text { fruit }\end{array}$ & $\begin{array}{l}\text { Shape of } \\
\text { fruits }\end{array}$ & Size fruit & $\begin{array}{l}\% \text { of } \\
\text { sugar }\end{array}$ & $\begin{array}{l}\text { Taste } \\
\text { of } \\
\text { fruit }\end{array}$ \\
\hline 1 & 3172 & $33 / 2$ & $\begin{array}{l}\text { Greenis } \\
\mathrm{h} \text { yellow }\end{array}$ & $\begin{array}{l}\text { Octobe } \\
\mathbf{r}\end{array}$ & $11 \times 7$ & 430 & irregular & large & 18 & Good \\
\hline 2 & 3170 & $33 / 2$ & green & $\begin{array}{l}\text { Octobe } \\
r\end{array}$ & $\begin{array}{l}10 x \\
4.5\end{array}$ & 370 & ovate & large & 19 & Good \\
\hline 3 & 3373 & $33 / 2$ & yellow & $\begin{array}{l}\text { Octobe } \\
r\end{array}$ & $10 \times 5$ & 220 & irregular & medium & 20 & Good \\
\hline 4 & 3173 & $33 / 1$ & $\begin{array}{l}\text { Green to } \\
\text { yellow }\end{array}$ & $\begin{array}{l}\text { Octobe } \\
\mathbf{r}\end{array}$ & $\begin{array}{l}12 \times 7 . \\
5\end{array}$ & 320 & ovate & medium & 19.5 & Good \\
\hline 5 & 3318 & $33 / 1$ & $\begin{array}{l}\text { Dark } \\
\text { green }\end{array}$ & $\begin{array}{l}\text { Octobe } \\
\mathrm{r}\end{array}$ & $10 \times 4$ & 150 & oblate & medium & 17 & Good \\
\hline
\end{tabular}


Vol. 06, No. 02; 2021

ISSN: 2456-8643

\begin{tabular}{|l|l|l|l|l|l|l|l|l|l|l|}
\hline 6 & 3141 & $33 / 2$ & $\begin{array}{l}\text { Green to } \\
\text { yellow }\end{array}$ & $\begin{array}{l}\text { Octobe } \\
\mathrm{r}\end{array}$ & $10 \times 6$ & 430 & pyres & medium & 18.5 & Good \\
\hline 7 & 3246 & $33 / 2$ & $\begin{array}{l}\text { Green to } \\
\text { yellow }\end{array}$ & $\begin{array}{l}\text { Octobe } \\
\mathrm{r}\end{array}$ & $9.5 \times 5$ & 480 & irregular & large & 18 & Good \\
\hline 8 & 3139 & $33 / 2$ & $\begin{array}{l}\text { Greenis } \\
\text { h/yell }\end{array}$ & $\begin{array}{l}\text { Octobe } \\
\mathrm{r}\end{array}$ & $5 \times 6$ & 250 & oblong & medium & 18 & Good \\
\hline 9 & 3295 & $33 / 2$ & yellow & $\begin{array}{l}\text { Octobe } \\
\mathrm{r}\end{array}$ & $9 \times 4.5$ & 210 & ovate & medium & 18.5 & Good \\
\hline 10 & 3287 & $33 / 2$ & $\begin{array}{l}\text { greenis } \\
\mathrm{h}\end{array}$ & $\begin{array}{l}\text { Octobe } \\
\mathrm{r}\end{array}$ & $11 \times 5$ & 370 & pyriform & large & 17 & Good \\
\hline
\end{tabular}

\section{Analysis of Variance}

Onaway Analysis of FL by Acc

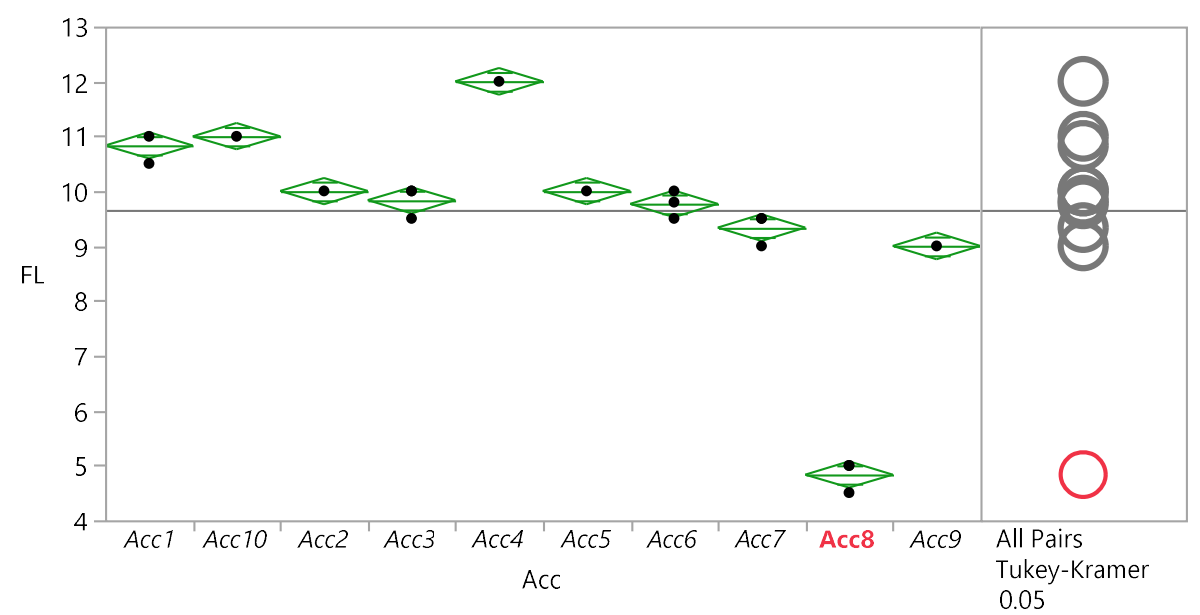

The other indicator that has been analyzed is sugar, which as seen from the analysis of variance shows that there is a limit line for all accessions from where the line is the limit is 19.3 with up to 20.5 and below 16 .

F ratio is greater than 0001

Represents the number of fruit variables, length and width of the fruit where there seems to be a heterogeneity between them. F ratio is more than $>$ theoretical $\mathrm{F}$.

From the analysis, the accesses are grouped into two groups, which are divided by the limit line between max and min. Most genotypes are homogeneous and are close to the limit line, while 
Vol. 06, No. 02; 2021

ISSN: $2456-8643$

two genotypes are heterogeneous with each other, one at max distance and the other at minimum distance.

\section{Onaway Anova}

This feature represents a pronounced variable, it is a quantitative feature. There is a heterogeneity between accessions. $\mathrm{F}$ ratio is $>$ that $\mathrm{F}$ theoretical.

It is noticed and here two groups in the first group are included Acc10, 2, 3, 5, 7, 9 and in the second group Acc 1, 4, 6, 8 .

This shows that there is a heterogeneity between the two groups, variability and within the group there are commonalities.

The meaning of test for at all couples comparison using Tukey - Kramer, which confirms the average which is 0.05 . This is same for two indexs and distance of fruit and weight. This has to do with quantitative indexs. The test has been intended to meaning of variable for some variable on one or more variables, when difference is $>0$ or over 0 in this case is 0.05 .

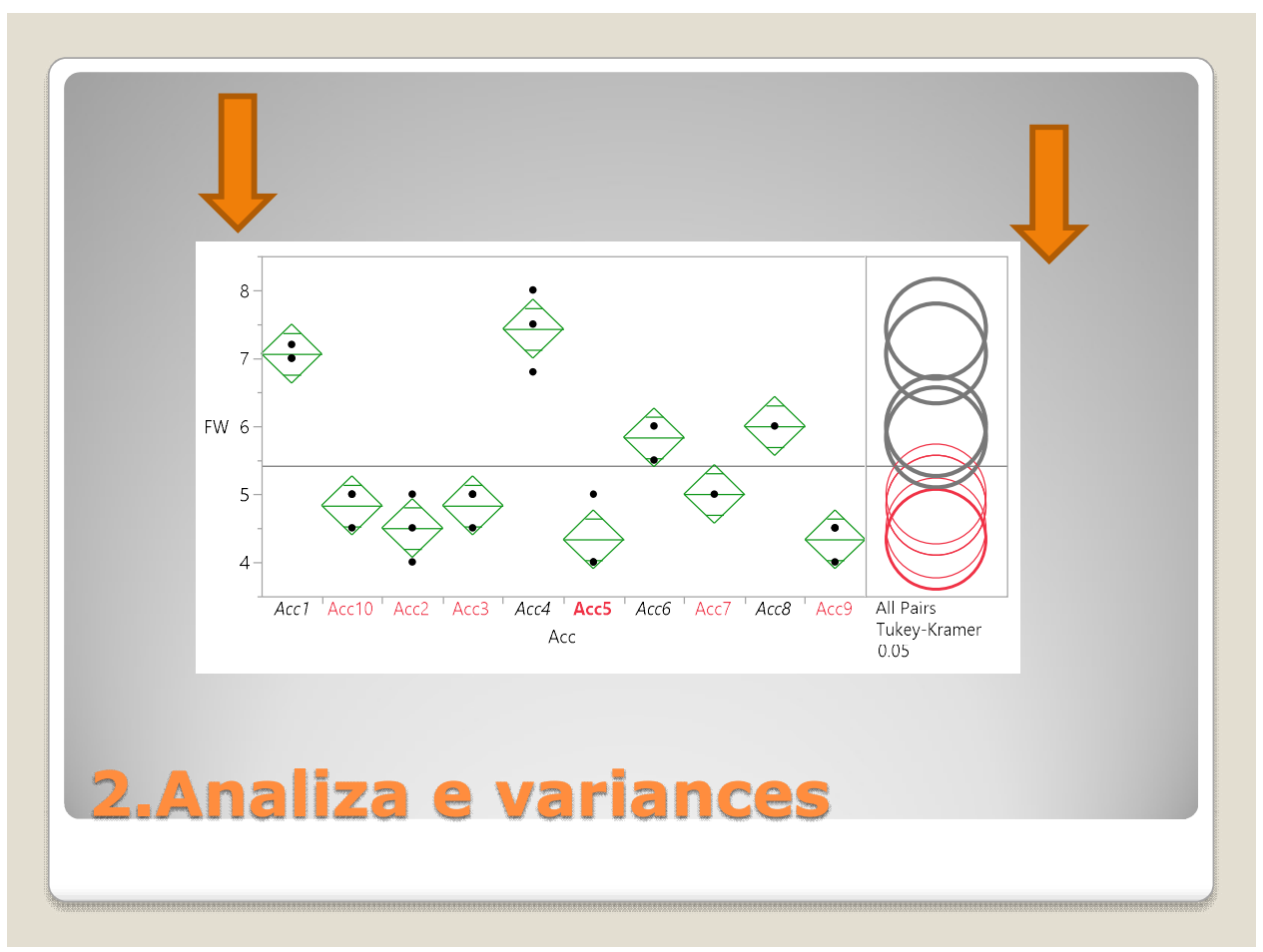

This feature represents a pronounced variable, it is a quantitative feature. There is heterogeneity between accessions. $\mathrm{F}$ ratio is $>$ that $\mathrm{F}$ theoretical.

It is noticed and here two groups in the first group are included Acc10, 2, 3, 5, 7, 9 and in the second group Acc 1, 4, 6, 8 . 
This shows that there is heterogeneity between the two groups, variability and within the group there are commonalities.

The meaning of the test for all pairs is compared using Tukey-Kramer, which confirms the average of 0.05; this is the same for both indicators of fruit and weight distances. This has to do with quantitative indicators. The test was intended to understand the variability for several variables in one or more variables, where the difference is less than o or above zero where in our case it is above 0 is 0.05 .

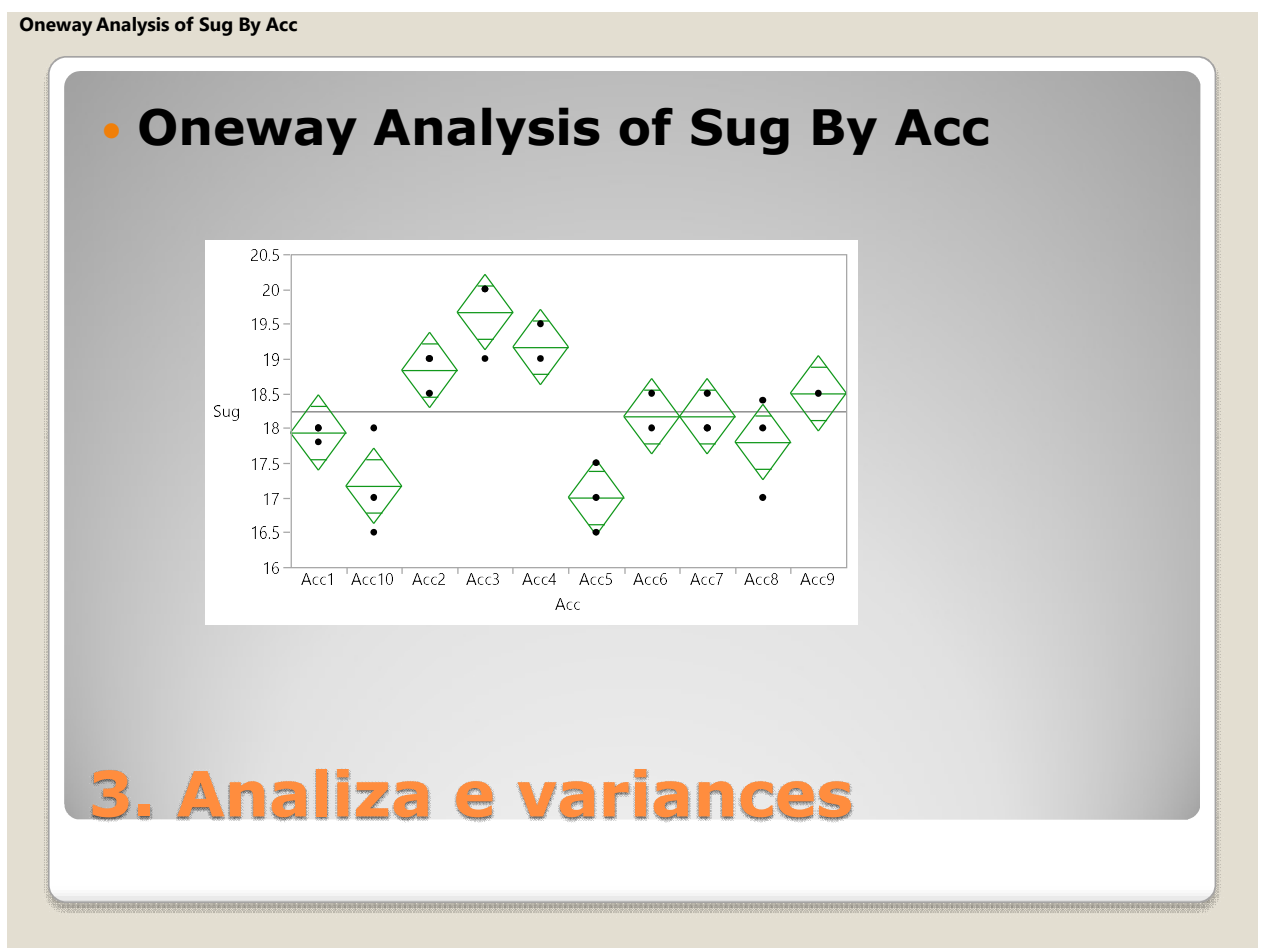

The other indicator that has been analyzed is sugar, which as seen from the analysis of variance shows that there is a limit line for all accessions from where the line is the limit is 19.3 with up to 20.5 and below 16.

F ratio is greater than 0001 


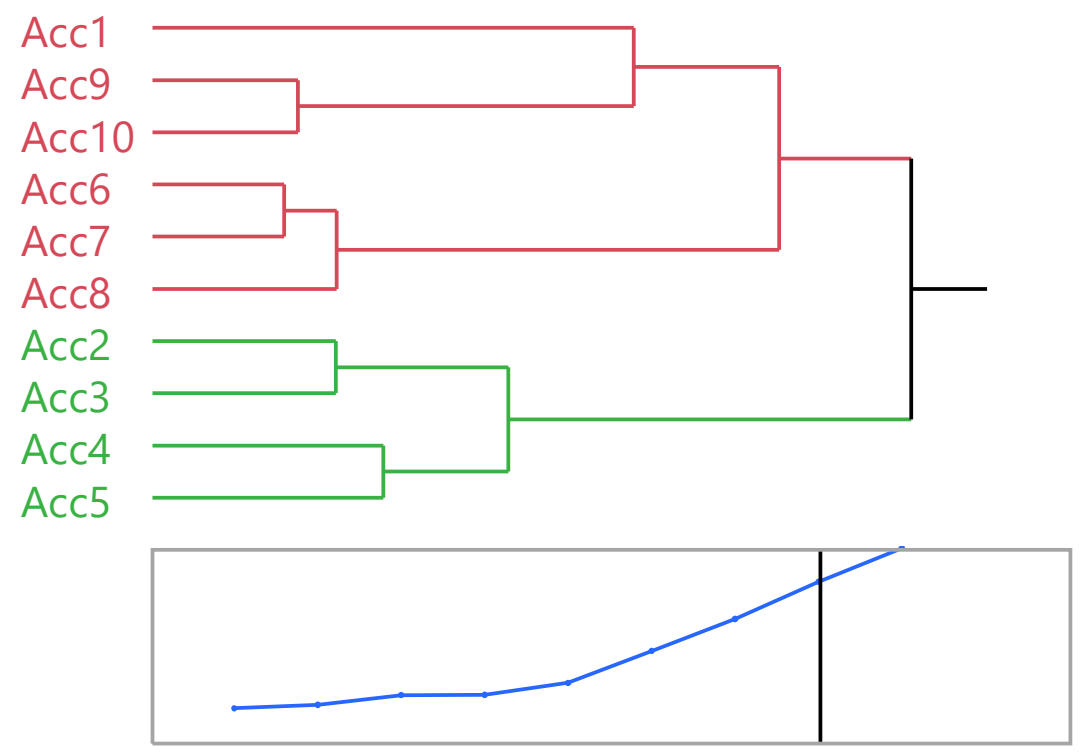

\section{Dendrogram}

Dendogram shows that accessions $1,9,6,7,8$, belong to a group with homogeneous features among them.

Accessions 2, 3, 4, 5 belong to the other group with homogeneous features between them. The features of accessions 1, 9, 10, 6, 7, 8 have distant features with accessions 2, 3, 4, 5, because they have a variety of features between them. This shows that in the collection are introduced genotypes with genetic diversity of traits. It shows that in our country we have invitations with diversity of traits, mainly in the fruit trait.

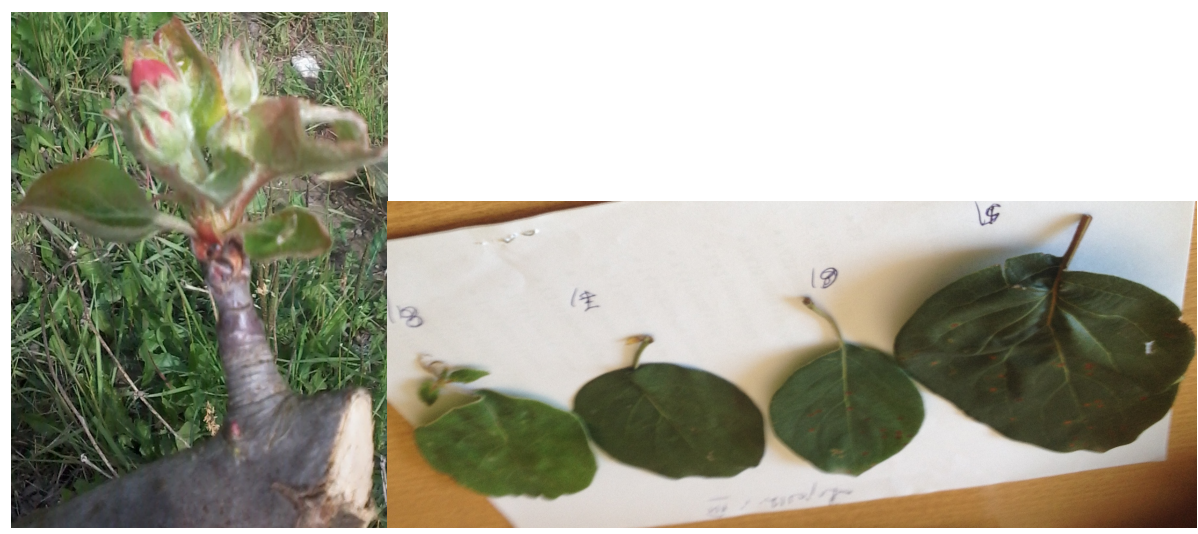




\section{International Journal of Agriculture, Environment and Bioresearch}

Vol. 06, No. 02; 2021

ISSN: 2456-8643
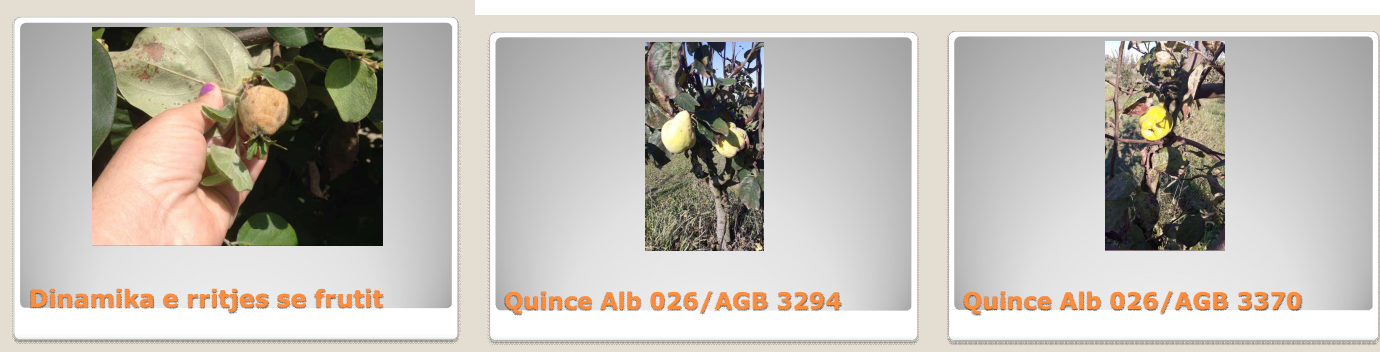

\section{2) Leaves diversity 3) Fructification 4)5) Cydonia accessions}

\section{CONCLUSION}

In the Valias collection there are invited species with genetic diversity, explored and studies in situ.

This species grows in our country in some areas, for the values it has increased the interest of cultivation and the market.

\section{Acknowledgement}

Thank the documentation and computerization office for this cooperation.

\section{REFERENCES}

1. Acikgor C (2011). Extraction and characterization of pectin obtained from quince fruits (Cydonia vulgaris pers) grown in Turkey. Asian J Chem. 23, 149-152.

2. Amir ME (2008). The status of genetic resource do deciduous, tropical and subtropical fruit species in Iran, Act Hortic 769; 159-163.

3. Baker BS, Bhatia SK (1993), Factors effecting adventitious shoot regeneration from leaf explants of quince (Cydonia oblonga). Plant cell tissue org cult 35; 273-277.

4. Bassil NV, Davis TM, Zhang H et al (2015). Development and preliminary evaluation of a 90 $\mathrm{K}$ Axiom SNP arroy for the allo-actoploid cultivated strawberry, Fragaric $\mathrm{x}$ ananassa BHC, Genomic 16; 15.

5. Bell RL, Leitao JM (2011), Cydonia, in Cole c (end) Wild crop relatives' genomic and breeding resources; temperate fruit, Berlin pp 11-16.

6. Bellini E, Giordano E (2000). Conservation of under - utilized fruit tree species in Europe, Act Hortic 522; 165-173. Uction and maintenance.

7. Bolton FJ (1990). An investigation of indirect conductimetry for detection of some food borne bacteria. J.Appl. Bacterial 69, 665-661.

8. Charties - Hollis JM (199). The induction and maintenance of autogenesis from und ferrentiated callus of Quince (cydonia oblonga). Act Hortic; 336; 321-326. 
Vol. 06, No. 02; 2021

ISSN: $2456-8643$

9. Daniel Zohary, Maria Hopf, Domestication of Plants in the Old World: The Origin and Spread of Cultivated Plants in West Asia, Europe, and the Nile Valley, Oxford University Press, 2000

10. Delcet - Sanjuan, R Mok DW, M ok Mc (1991). Plant regeneration from cultured leaves of cydonia oblonga L (quince). Plant cell Rep; 10; 240 - 242.

11. European Commission (2007), Minor fruit tree species; conservation, evaluation, exploitation and collection of minor fruit species. 1467/94 pp 56-59. Fao.org/site/567.

12. Eddy A.A (1996). Interstitial inflammation and fibrosis in rats with diet induced hypercholester olemia, kiney Int, 50, 119-1149.

13. Fattouches S, Caboni P, Coronco Vet et al (2007), Antimerobial activity of Tunusian quince (cydonia oblonga Millier) pulp and peel poly phenol extracts. J.Agric Food Chem. 55; 963-966.

14. Fornix E, Pen chi M, Polosello A (1994). A preliminary characterization of some pectin's from quince fruit ( cydonia oblonga Mill) and prickly pears ( Opunitia ficus indica) peel carbohyde, Polym 23; 231-234.

15.Ghopur H, Usmanovalis S K, Ayupbek A, Aisa HA (2012). New chrome from seeds of chydonia oblonga, Chem Nat Coup 48, 562-564.

16. Murcia MA Jimenez, A.M.Martinez, Tome M (2001). Evaluation of the antioxidant properties of Mediterranean and tropical fruits compared with common food additives, JFoodProt 64, 2037-2046.

17. P.Zorba, Buletini klimatik, Gjeoshkenca, 2019.

18. Wilson, C. Anne. The Book of Marmalade: Its Antecedents, Its History and Its Role in the World Today (Together with a Collection of Recipes for Marmalades and Marmalade Cookery), University of Pennsylvania Press, Philadelphia. Revised Edition 1999.

ISBN 0-8122-1727. 